\title{
PENGEMBANGAN BUSANA FANTASI DENGAN SUMBER IDE KEKAISARAN JEPANG
}

\author{
Ayu Putu Rahayu Pertiwi Lestari, I Gede Sudirtha, Made Diah Angendari \\ Jurusan Pendidikan Kesejahteraan Keluarga \\ Universitas Pendidikan Ganesha \\ Singaraja, Indonesia \\ e-mail : rahayu1096@yahoo.co.id gede.sudirtha@undiksha.ac.id \\ diah.angendari@undiksha.ac.id
}

\begin{abstract}
Abstrak
Tujuan Penelitian ini adalah 1) mendeskripsikan proses pengembangan busana fantasi 2) mengetahui hasil pengembangan pembuatan busana fantasi dengan sumber ide Kekaisaran Jepang. Dalam penelitian ini menggunakan model penelitian pengembangan dengan model ADDIE (Analysis-Design-Development-Implementation-Evaluation) pada setiap tahapannya. Instrument yang digunakan dalam penelitian ini berupa lembar kuisoner diberikan kepada Expert Judgment untuk menguji instrument sebelum diberikan ke ahli produk dan selanjutnya dianalisis dengan menggunakan teknik analisis kualitatif dan kuantitatif. Adapun hasil penelitian menunjukkan 1) Proses penelitian pengembangan busana fantasi dengan sumber ide kekaisaran Jepang menggunakan model ADDIE terdiri dari beberapa langkah-langkahnya, a) analisis busana b) mendesain busana, c) pengembangan busana d) mengimplementasikan busana e) mengevaluasi busana. 2) Hasil pengembangan busana fantasi dengan sumber ide Kekaisaran Jepang, dari hasil iuji oleh dua orang ahli produk, mendapatkan nilai $77,27 \%$ dengan hasil kualifikasi baik. Sehingga bisa dijadikan acuan dalam mengembangkan sebuah produk selanjutnya.
\end{abstract}

Kata Kunci : ADDIE, Busana Fantasi, Kekaisaran Jepang, Pengembangan

\begin{abstract}
The objectives of this study were 1) to describe the process of developing fantasy fashion 2) to know the results of the development of making fantasy fashion with the source of the idea of the Imperial Japan. In this study using a development research model with ADDIE (AnalysisDesign-Development-Implementation-Evaluation) model at each stage. The instrument used in this study in the form of questionnaire was given to Expert Judgment to test the instrument before being given to the product expert and then analyzed using qualitative and quantitative analysis techniques. The results of the study show 1) The process of researching the development of fantasy fashion with sources of imperial Japanese ideas using the ADDIE model consists of several steps, a) fashion analysis with b) designing clothes, c) fashion development, d) implementing fashion, e) evaluating fashion . 2) The results of the development of fantasy fashion with the source of the idea of Imperial Japan, from the results of the tests by two product experts, scored $77.27 \%$ with good qualifications. So that it can be used as a reference in developing a further product.
\end{abstract}

Keywords: ADDIE, Development, Fantasy Fashion, Imperial Japan

\section{PENDAHULUAN}

Busana merupakan segala sesuatu yang dipakai dimulai dari ujung rambut sampai ujung kaki. Busana mencakup busana pokok dan pelengkap (milineris dan aksesoris) dan 
tata riasnya. Menurut Arifah A. Riyanto (2003:2), Busana juga mencerminkan sejarah, hubungan kekuasaan, serta perbedaan dalam pandangan sosial, politik, dan religius.

Perkembangan teknologi dapat mempengaruhi kehidupan dan kebudayaan manusia, demikian juga dalam hal berbusana. Melalui media komunikasi seperti televisi, majalah dan internet sangat menunjang sekali untuk perkembangan tren mode busana, karena melalui media tersebut kita dapat melihat langsung tren mode yang sedang berkembang diseluruh penjuru dunia, di setiap negara terdapat banyak sekali bentuk busana yang beraneka ragam sesuai dengan iklim, dan pola hidup, terdapat banyak budaya yang berkembang, mempengaruhi bentuk dan model busana yang menjadi salah satu dalam pembuatan busana. Salah satunya di Benua Asia, Benua Asia merupakan benua yang masih banyak negaranya yang mempertahankan budayanya, Salah satu negara di Benua Asia yang terkenal yang masih mempertahankan budayanya serta busananya yang sangat terkenal di era modern ini yaitu Jepang.

Jepang adalah sebuah negara yang menyimpan keunikan pada hal kebudayaan. Kebudayaan Jepang dipengaruhi oleh karakteristik geografis negaranya serta mempunyai pengaruh timbal balik dengan karakteristik rakyatnya. Bangsa Jepang umumnya dikenal sebagai bangsa yang mampu mengambil dan menarik manfaat dari hasil budi daya bangsa lain, tanpa mengorbankan kepribadiannya sendiri.

Di Jepang menganut sistem negara monarki konstitusional dimana kekuasaan Kaisar Jepang sangat dibatasi. Keluarga kekaisaran Jepang sangat dihormati secara luas oleh rakyat Jepang. Di keluarga kekaisaran Jepang menggunakan kimono merupakan hal yang sangat penting secara turun-temurun sebagai keluarga kerajaan, kimono merupakan busana tradisional Jepang yang masih saat ini dilestarikan dan

menjadi busana nasional bangsa Jepang, terbuat dari sutra dengan motif dan warna yang mencolok diseluruh bagian kain, serta terdapat lambang keluarga. Penggunaan kimono yang kurang praktis membuat keluarga kekaisaran Jepang menggunakannya untuk acara tertentu ataupun acara formal saja.

Kimono adalah busana secara turun-temurun digunakan sejak Jepang berada dalam zaman Jomon dan zaman Yayoi (660 SM - 552SM) hingga masa kini, sehingga kimono menjadi pakaian nasional Jepang. Kata 'kimono' berasal dari kata ki yang berarti memakai dan kata monoyang artinya adalah barang. Arti harafiah dari kimono adalah sesuatu yang dipakai atau busana. Menurut Gakukan Shoi (2000 : 164 ) definisi makna kata kimono adalah sebagai berikut :

"Istilah umum untuk sesuatu yang dipakai di badan. busana tradisional Jepang dan busana khas Jepang"

Kimono mengalami perubahan bentuk dan motif seiring dengan perubahan zaman Negara Jepang. Seperti pada periode Heian (785-1185) mempunyai ketertarikan yang besar dalam bidang busana, sehingga kimono yang paling terkenal pada masa itu adalah kimono yang terdiri dari 12 lapis atau disebut jyuuni-hitoe, yang masingmasing lapisan lebih besar dan ringan dibanding lapisan sebelumnya. Pada zaman Kamakura (1185- 1333), para bangsawan memilih jenis busana orang awam yang praktis dan lebih nyaman. Para wanita bangsawan membuang semua lapisan jyuuni-hitoeyang merepotkan, serta 'lengan kimono lebar' (osode) lalu mengadaptasi kosode (kimono dengan lebar lengan yang lebih pendek dari (osode) dan hakama (celana panjang yang tergerai), yang merupakan pakaian dalam bagi wanita bangsawan di Kyoto dan juga pakaian luar bagi rakyat jelata.. 
Kimono berbentuk huruf "T" dan cenderung lebih mirip mantel lengan panjang berkerah. Kimono biasa dibuat panjang hingga mata kaki. Untuk wanita, kimono berbentuk terusan, sedangkan pria menggunakan kimono yang berbentuk setelan (baju dan celana). Menggunakan obi yang dililitkan dibagian perut dan pinggang, tali yang dililitkan di obi disebut obijime, hiasan rambut menggunakan kanzashi yaitu hiasan kepala dari bunga yang di sematkan di rambut. Sedangkan alas kaki yang digunakan pada saat menggunakan kimono disebut zori atau geta. (dikutip dari : http://id.wikipedia.org/wiki/kimono, 2018).

Kimono memilik makna dan arti filosofis dan ini dapat dilihat melalui pemilihan warna. Pemilihan warna kimono yang tepat membutuhkan pengetahuan tentang simbiolisme dan isyarat tersembunyi setiap jenis warna kimono. Kimono wanita muda berwarna cerah dan lembut, mencerminkan emosi tertentu atau berhubungan dengan alam ataupun kesempatan, ketika berfungsi untuk memberikan keberuntungan bagai pemakainya. Warna juga digunakan sebagai pengembangan kebudayaan. Pada zaman dahulu Bangsa Jepang pun menggunakan warna sebagai salah satu komunikasi nonverbal.

Pada zaman sebelum negara ini bersentuhan dengan dunia luar, masyarakat Jepang mengenakan busana tradisional seperti kimono. Meskipun negara ini mendapat pengaruh dari negara-negara barat, Jepang memiliki ciri khas tersendiri pada mode busananya. $\mathrm{Hal}$ ini disebabkan karena mode-mode busana tersebut diciptakan oleh masyarakat Jepang sendiri dengan memadukan unsur budaya yang mereka miliki.

Dari uraian di atas maka peneliti akan melakukan penelitian pengembangan dengan model ADDIE (Analysis, Design, Development, Implementation, Evaluasi). Penelitian pengembangan memiliki banyak sekali model pengembangan, salah satunya adalah penelitian dengan model ADDIE. Peneliti memilih penelitian pengembangan dengan model ADDIE dikarenakan model penelitian ini memiliki langkah-langkah yang mudah yang diterapkan untuk mengembangkan produk dimana peneliti akan mengembangkan sebuah produk busana dengan mengambil sumber ide di kekaisaran Jepang. Peneliti akan melakukan pengembangan berupa busana fantasi yaitu busana yang tercipta dari khayalan ataupun angan-angan yang ada dalam benak atau pikiran. meliputi tema, desain, pemilihan bahan, pembuatan busana dan proses pengepasan.

\section{METODE}

Penelitian ini merupakan jenis penelitian dan pengembangan atau Research and Development (R\&D). Menurut Sugiyono (2012:407) penelitian dan pengembangan adalah metode penelitian yang digunakan untuk menghasilkan produk tertentu, dan menguji keefektifan produk tersebut. Jadi penelitian pengembangan merupakan metode untuk menghasilkan produk tertentu atau menyempurnakan produk yang telah ada serta menguji keefektifan produk tersebut. Dalam penelitian ini menggunakan model penelitian pengembangan ADDIE (Analysis, Design, Development, Implementation, Evaluation). Pemilihan penelitian pengembangan dengan model ADDIE ini memperlihatkan tahapan-tahapan dasar desain pengembangan yang sederhana dan mudah untuk dipelajari.

Disini peneliti melakukan penelitian dengan mengembangkan busana fantasi dengan sumber ide kekaisaran Jepang. Untuk berinovasi dalam menciptakan suatu produk dalam pembuatan busana serta mengefektifkan produk yang telah dibuat. 


$\begin{gathered}\text { Prosedur } \\ \text { penelitian in } \\ \text { menggunakan } \\ \text { Model penelitian }\end{gathered}$
pengembangan Analysis-Design-
Development-Implementation-
Evaluation (ADDIE). Muncul pada
tahun 1990-an yang dikembangkan oleh Reiser dan Mollenda. Penelitian pengembangan ADDIE merupakan model desain pembelajaran atau pelatihan yang bersifat generik menjadi pedoman dalam membangun perangkat dan infrastruktur program pelatihan yang efektif, dinamis dan mendukung kinerja pelatihan itu sendiri. Prosedur penelitian pengembangan ini terdiri dari beberapa tahap yaitu : 1) Analisis, 2) Desain, 3) Pengembangan, 4) Implementasi 5) Evaluasi.

Menganalisis model busana yang digunakan di kekaisaran Jepang sesuai budaya yang ada di Jepang sebelum mengembangkannya. Busana dengan jenis busana fantasi. Disini peneliti mengambil inspirasi dari lengan kimono, yang memiliki ciri khas menggunakan lengan panjang lebar yang menjuntai. Yang peneliti analisis terlebih dahulu untuk dikembangkan, Selain itu peneliti menggambil dari ciri khas obi, obi merupakan ikat pinggang khas Jepang yang digunakan saat memakai kimono bentuknya yang lebar menutupi perut, dimana kimono menggunakan obi sebagai center of interest dalam pemakaiannya. Menganalisis warna yang biasa digunakan, dan warna yang memiliki symbol ataupun makna-makna oleh orang Jepang. Disini peneliti menggunakan warna biru muda, merah muda dan ungu. Biru muda yang peneliti ambil dari warna-warna alam seperti langit, sedangkan warna merah muda peneliti ambil karena salah satu ciri khas negara Jepang dengan bunga sakura yang memiliki warna merah muda, sedangkan warna ungu merupakan warna yang melambangkan keistimewaan pada kekaisaran Jepang, warna ungu ini biasa digunakan pada mahkota atau jubah kaisar atau putri di Jepang.
Selanjutnya peneliti membuat suatu desain dengan merancang menggambar busana fantasi hasil pengembangan busana kekaisaran Jepang. Tiga desain yang peneliti buat yang nantinya akan peneliti pilih adalah dua desain yang akan dikembangkan dengan karakteristik busana fantasi dengan sumber ide kimono.

Tahapan pengembangan Peneliti melakukan pengembangan busana, dengan merancang bahan yang akan digunakan, memilih bahan yang cocok yang akan digunakan, membeli bahan, membuat pola dasar dan mengembangkannya sesuai dengan desain yang telah dipilih, memotong bahan sesuai pola lalu menjahit, menghias dan melakukan finishing.

Selanjutnya peneliti melakukan implementasi dengan menggunakan busana tersebut kepada model yang telah di pilih peneliti sebelumnya untuk menggunakan busana tersebut. Sehingga peneliti dapat mengetahui bentuk busana tersebut ketika telah digunakan oleh model yang akan memperagakannya.

Tahapan terakhir peneliti melakukan tahapan evaluasi, dimana peneliti membuat instrument penilaian ke ahli terkait busana yang dikembangkan, yang nantinya produk tersebut mendapat kelayakan dan saran dari ahli guna meningkatkan karya peneliti.

Produk pengembangan busana dibuat dengan rancangan sebuah desain untuk menguji kesesuaian produk terhadap hasil pengembangan. Sebelum membuat produk terlebih dahulu membuat desain atau merancang suatu produk, kemudian desain atau rancangan yang telah dibuat disesuaikan dengan karakteristik yang akan dibuat. Produk yang akan di uji cobakan hasil busana fantasi mulai dari rancangan hingga penerapannya. pada tingkat validasi pengembangan dilakukan oleh ahli 
(Expert Judgement) yang bertugas mengevaluasi instrument sebelum disebarkan kepada uji produk. Penelitian ini menggunakan analisis gregori dimana menggunakan 2 orang

\begin{tabular}{|c|c|c|c|}
\hline & & \multicolumn{2}{|c|}{ Penilai 1} \\
\hline & & $\begin{array}{l}\text { Kurang } \\
\text { Relevan } \\
\text { (skor1-2) }\end{array}$ & $\begin{array}{l}\text { Sangat } \\
\text { Relevan } \\
\text { (skor3-4) }\end{array}$ \\
\hline $\begin{array}{l}\bar{\sigma} \\
\overline{\bar{\sigma}} \\
\alpha \text { D }\end{array}$ & $\begin{array}{l}\text { Kurang } \\
\text { Relevan } \\
\text { (skor1-2) }\end{array}$ & $\begin{array}{l}(A) \\
(1)\end{array}$ & (B) \\
\hline & $\begin{array}{l}\text { Sangat } \\
\text { Releva } \\
\text { (skor3-4) }\end{array}$ & (C) & $\begin{array}{l}\text { (D) } \\
(11)\end{array}$ \\
\hline
\end{tabular}

ahli. Tingkat validasi pengembangan busana fantasi dilaksanakan dengan 2 tahapan yaitu : 1) evaluasi dilakukan oleh ahli isi, dimana sebelum instrument yang akan disebarkan kepada ahli produk di evaluasi untuk menguji produk, pada tahapan ini menggunakan dosen dijurusan pendidikan kesejahteraan keluarga program studi tata busana. 2) pada uji produk tingkat validasi pengembangan busana fantasi ini dilakukan dengan ahli produk untuk mengetahui kelayakan produk yang telah dibuat, menggunakan ahli yang merupakan guru SMK Negeri 2 Singaraja dan

Owner Ria Boutique di Singaraja.

Data yang diperoleh dalam proses pengembangan busana fantasi berupa data kualitatif dan data kuantitatif. Data kualitatif diperoleh melalui hasil review dari ahli instrument dan ahli produk yang hasilnya didapatkan melalui pengumpulan kuisioner. Sedangkan data kuantitatif diperoleh dari data kualitatif kuisioner yang dikumpulkan menjadi skor atau nilai.

Metode yang digunakan dalam mengetahui kualitas produk yaitu dengan metode kuesioner/angket. Metode kuesioner adalah teknik pengambilan data dengan memberikan pertanyaan atau pernyataan kepada orang lain yang akan dijadikan subyek penelitian. Secara umum instrument adalah suatu alat yang memenuhi persyaratan akademis, sehingga dapat dipergunakan sebagai alat untuk mengukur suatu objek ukur atau mengumpulkan data mengenai suatu variable. Instrument penilaian yang digunakan para review para ahli dalam menilai hasil pengembangan busana dengan sumber ide kekaisaran Jepang. Adapun hasil dari penilaian ahli isi yaitu :

Tabel 1. Hasil Penilaian Ahli Isi

Dari tabel diatas dapat dicari validitas isi dengan menggunakan rumus Greogory.

Validitas Isi $=$

$$
\begin{aligned}
& \overline{A+B+C+D} \\
= & \frac{11}{12} \\
= & 0,91
\end{aligned}
$$

Jadi validitas isi instrument adalah 0,91 maka instrument dapat dikatakan valid.

Adapun rumus yang akan digunakan untuk menghitung hasil uji produk sebagai berikut.

Presentase $=\frac{\left.\sum \text { (jawaban } \times \text { bobot tiap pilihan }\right)}{n \times \text { bobot tertinggi }} \times 100 \%$

Keterangan: $\Sigma=$ jumlah

$\mathrm{n}=$ jumlah seluruh item angket.

Selanjutnya setelah menghitung presentase, maka bisa ditetapkan dengan konvensi tingkat pencapaian.

Tabel 2. Konvensi Tingkat Pencapaian Skala 
Selanjutnya hasil data diatas diolah menggunakan teknik analisis deskriptif kualitatif yang berupa hasil review ahli produk. Teknik analisis ini dilakukan dengan mengelompokan informasiinformasi dari data kualitatif yang berupa masukan, tanggapan, kritik dan saran perbaikan yang terdapat pada lembar instrument penilaian. Hasil analisis ini yng digunakan untuk merevisi produk yang dikembangkan.

\section{HASIL DAN PEMBAHASAN Hasil Penelitian}

Pada bab ini akan dipaparkaan hasil penelitian sesuai dengan rumusan masalah penelitian yang telah dirumuskan, yaitu: 1) Bagaimana proses pengembangan busana fantasi dengan sumber ide Kekaisaran Jepang. 2) Bagaimana hasil akhir pengembangan busana fantasi dengan sumber ide Kekaisaran Jepang. Dari penilaian ahli instrumen serta ahli produk sebagai hasil dari penelitian, terdapat beberapa hasil dari pengembangan busana fantasi dengan sumber Kekaisaran Jepang. Bedasarkan langkah dalam penelitian pengembangan ADDIE, maka didapatkan hasil sebagai berikut:

\section{Proses Pengembangan Busana Fantasi Dengan Sumber Ide Kekaisaran Jepang.}

Dalam mengembangkan suatu produk perlu adanya tahapan-tahapan agar suatu produk yang dikembangkan dapat berjalan dengan baik, berikut merupakan proses peneliti dalam melakukan pengembangan diantaranya ada lima tahapan :

Tahap pertama yang peneliti lakukan yaitu menganalisis busana tradisional jepang yaitu kimono, dimana kimono merupakan busana yang digunakan oleh keluarga dikekaisaran jepang kimono yang identik dengan keceriaan, budaya dan menampilkan sosok wanita jepang yang cantik dan anggun. Disini peneliti menganalisis

\begin{tabular}{ll}
\hline Tingkat \\
Pencapaian & Kualifikasi \\
\hline $90 \%-100 \%$ & Sangat Baik \\
$75 \%-89 \%$ & Baik \\
$65 \%-74 \%$ & Cukup \\
$55 \%-64 \%$ & Kurang \\
$0-54 \%$ & Sangat Kurang \\
\hline
\end{tabular}

untuk mengambil bentuk dari lengan kimono serta obi kemudian peneliti melakukan analisis selanjutnya dari kebudayaan jepang. Selanjutnya menggunakan yaitu tatanan rambut, makeup yaitu dari geisha jepang seorang wanita jepang yang terkenal akan kecantikannya. Kemudian peneliti menganalisis warna-warna dijepang yang nanti akan digunakan. Peneliti mengambil warna-warna yang dipercayai membawa keberuntungan, kasih sayang dan warna yang menjadi salah satu ciri khas Jepang. Pada tahapan ini analisis ini dilakukan melalui proses evaluasi agar sesuai dengan yang direncanakan yang nantinya produk yang dihasilkan berupa busana fantasi yang nanti peneliti ciptakan diharapkan masih mempunyai nilai atau ciri khas negara Jepang saat sudah dikembangkan.

Pada tahap kedua ini yang peneliti lakukan yaitu merancang busana fantasi yang ingin dikembangkan dari analisis yang telah dilakukan. Adapun desain sketsa yang telah peneliti buat yaitu sebanyak empat desain Disini rancangan busana fantasi disesuaikan dengan menggunakan tiga warna yaitu warna merah muda yaitu warna dari bunga sakura yang melambangkan ikon negara Jepang selain itu bunga sakura memiliki arti sebagai rasa kasih sayang, kemudian peneliti memlih warna biru muda yaitu warna yang menggambarkan langit yang merupakan warna ketenangan dan menyejukan, Ialu peneliti memilih warna ungu, yang memiliki warna yang digunakan oleh mahkota kerjaan di Jepang, nantinya warna ini dipadukan dengan busana fantasi yang menampilkan seorang putri jepang yang cantik dan anggun, selain busana 
disini peneliti membuat desain produksi menjelaskan bahan apa saja yang digunakan serta bentuk busana fantasi yang dibuat. Adapun bahan yang digunakan yaitu bahan utama kain jaguar yang berwarna merah muda sebagai atasan, dan kain satin berwana biru muda pada bagian bawah. Kain yang digunakan pada obi menggunakan beludru berwarna ungu, selain itu menggunakan kain sifon sebagai bahan tambahan pada bagian lengan, dan menggunakan furing hero sebagai lapisan.

Setelah tahap kedua desain telah selesai, peneliti melanjutkan dengan tahap ketiga yaitu pengembangan. Disini yang peneliti kembangkan yaitu busana fantasi. Peneliti mengembangkan busana kimono kedalam bentuk modern yang mempunyai daya pakai praktis. Tahap ini peneliti melakukan proses pembuatan busana fantasi dengan mengembangkannya dengan langkah langkah mengambil ukuran, membuat pola kecil, merancang bahan, membuat pola besar, menyiapkan alat dan bahan, memotong bahan, menjahit bahan dan melakukan finishing.

Melalui tahap pengembangan, selanjutnya tahap implementasi, yaitu tahapan untuk menerapkan pengembangan. Pada tahapan ini peneliti membuat pengembangan busana fantasi ini digunakan oleh seorang model. Pada tahap ini dilakukan penilaian oleh ahli untuk mengetahui kelayakan produk yang sudah dikembangkan. Agar mendapat kelayakan produk yang telah dikembangkan, peneliti menggunakan ahli produk untuk menguji kelayakan produk. Peneliti menggunakan lembar kuisoner yang sudah dievaluasi oleh ahli isi untuk mengevaluasi instrument, insrument terdiri dari 3 kriteria penilaian dan 11 butir penyataan. Berikut ini peneliti hasil dari penilaian produk oleh ahli produk

Tabel 3. Hasil Penilaian Produk

\begin{tabular}{ll}
\hline \multicolumn{2}{c}{ Penilaian Hasil Produk } \\
\hline Hasil Ahli Poduk 1 & $74,54 \%$ \\
Hasil Ahli Produk 2 & $80 \%$ \\
Rerata Persentase & $77,2 \%$ \\
\hline
\end{tabular}

Jadi tingkat pencapaian validitas produk adalah $77,27 \%$ dengan penghitungan tersebut, maka kelayakan produk dapat dikatakan baik.

Tahapan yang terakhir yaitu evaluasi, disetiap tahapan peneliti tidak lepas dari evaluasi. Evaluasi berarti proses menentukan nilai untuk suatu hal atau objek yang berdasarkan pada acuan-acuan tertentu untuk menentukan tujuan tertentu. Pada evaluasi ini terlihat suatu produk yang telah dibuat berhasil atau tidak. Pada evaluasi ini penilaian produk dari ahli isi dan ahli produk memperbaiki ataupun menjadi sebagai acuan dalam mengembangkan suatu produk untuk kedepannya. Adapun masukan dari para ahli yaitu:

Tabel 4. Saran Ahli Produk

\begin{tabular}{llll}
\hline Hasil Penilaian Oleh Para Ahli isi & $\begin{array}{l}\text { Hasil Penilaian Oleh Para Ahli } \\
\text { Produk }\end{array}$ \\
\hline $\begin{array}{l}\text { 1. Ahli isi menilai instrumen } \\
\text { pengembangan busana fantasi } \\
\text { dengan sumber ide kekaisaran } \\
\text { Jepang dengan hasil valid }\end{array}$ & $\begin{array}{l}\text { 1. Ahli } \\
\text { pengembangan busana fantasi } \\
\text { dengan sumber ide kekaisaran } \\
\text { Jepang dengan kualifikasi baik }\end{array}$ \\
$\begin{array}{l}\text { 2. Ahli isi juga memberikan saran } \\
\text { untuk memperbaiki butir-butir } \\
\text { yang kurang jelas sehingga } \\
\text { dapat digunakan kembali untuk }\end{array}$ & $\begin{array}{l}\text { 2. Ahli produk memberikan saran } \\
\text { dan masukan terkait produk } \\
\text { pengembangan busana fantasi }\end{array}$ \\
\hline
\end{tabular}


Jurnal Bosaparis: Pendidikan Kesejahteraan Keluarga

Volume 9, Nomor 3, November 2018

mevalidasi produk.

3. Ahli memberikan saran dan masukan terkait produk yang akan dinilai.

\section{Hasil Akhir Pengembangan Busana Fantasi Dengan Sumber Ide Kekaisaran Jepang.}

Produk yang dikembangkan dalam penelitian ini adalah busana fantasi dengan sumber ide Kekaisaran Jepang. Dari tahaptahapan pengembangan ADDIE yang terdiri dari (analisis, desain, pengembangan, implementasi dan evaluasi) peneliti lakukan, dapat dilampirkan sebagai berikut.

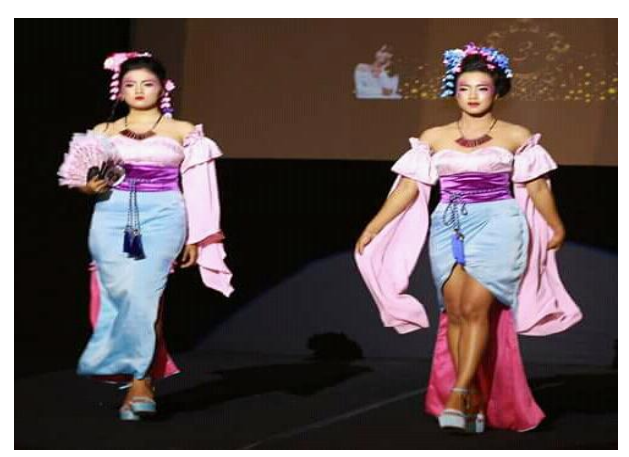

Gambar 1. Busana Fantasi Tampak Dari Depan

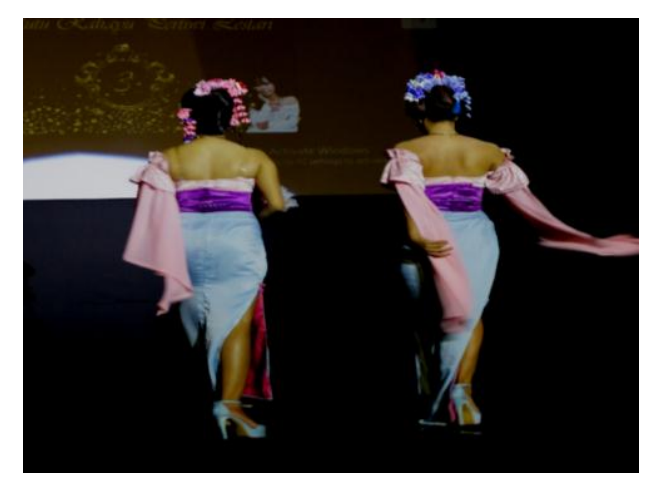

Gambar 2. Busana Fantasi Tampak Dari Belakang

\section{PEMBAHASAN}

Proses Pengembangan Busana Fantasi
Dengan Sumber Ide Kekaisaran Jepang. Dalam proses pengembangan busana fantasi dengan sumber ide kekaisaran Jepang ini menggunakan model ADDIE (analysis, design, development, implementation, evaluation). Pada tahap pertama peneliti melakukan tahap pertama yyaitu menganalisis busana tradisional jepang yaitu kimono, dimana kimono merupakan busana yang digunakan oleh keluarga dikekaisaran Jepang kimono yang identik dengan keceriaan, budaya dan menampilkan sosok wanita jepang yang cantik dan anggun. disini peneliti menganalisis untuk mengambil bentuk dari lengan kimono serta obi kemudian peneliti melakukan analisis selanjutnya dari kebudayaan jepang selain menggunakan kimono yaitu tatanan rambut, makeup yaitu dari geisha jepang seorang wanita jepang yang terkenal akan kecantikannya serta warna-warna yang dipercayai membawa keberuntungan dan kasih sayang.

Setelah menganalisis selanjutnya peneliti melanjutkan dengan tahapan desain ada tahap kedua ini yang peneliti lakukan yaitu merancang busana fantasi yang ingin dikembangkan dari analisis yang telah dilakukan. Disini rancangan busana fantasi disesuaikan dengan peneliti menggunakan tiga buah warna yaitu warna merah muda yaitu warna dari bunga sakura yang melambangkan icon negara Jepang selain itu bunga sakura memiliki arti sebagai rasa kasih sayang, jepang yang cantik dan anggun.

Peneliti melakukan tahapan selanjutnya yaitu pengembangan. Disini yang peneliti kembangkan yaitu busana fantasi. Peneliti mengembangkan busana kimono kedalam bentuk modern yang mempunyai daya pakai praktis. Tahap ini peneliti melakukan proses pembuatan busana fantasi dengan 
mengembangkannya dengan langkah langkah mengambil ukuran, membuat pola kecil, merancang bahan, membuat pola besar, menyiapkan alat dan bahan, memotong bahan, menjahit bahan dan melakukan finishing.

Melalui tahap pengembangan, selanjutnya tahap implementasi, yaitu tahapan untuk menerapkan pengembangan. Pada tahapan ini peneliti membuat pengembangan busana fantasi ini digunakan oleh seorang model. Pada tahap ini dilakukan penilaian oleh ahli untuk mengetahui validitas dan kelayakan produk yang sudah dikembangkan. Pada penelitian ini validitas isi dilakukan oleh dua orang ahli, dengan hasil evaluasi instrument adalah 0,91 maka instrument dapat dikatakan valid karena terdapat rentang kriteria derajat validitas sangat tinggi.

Selanjutnya untuk mengetahui kelayakan produk busana fantasi yang telah dikembangkan maka peneliti melakukan uji produk menggunakan instrumen penilaian, uji produk dilakukan oleh dua orang ahli, ahli pertama berasal dari seorang praktisi industri busana Ria Boutique yang bertempat di Singaraja dan ahli kedua seorang guru jurusan tata busana SMKN 2 Singaraja.Hasil uji produk pengembangan busana yang terlihat pada tabel memperlihatkan hasil uji produk ahli 1 dengan presentase $74,54 \%$ dan ahli 2 dengan presentase $80 \%$ dengan total kedua ahli yaitu $77,27 \%$ dengan penghitungan tersebut, maka kualifikasi produk pengembangan busana dengan sumber ide Kekaisaran Jepang dengan kualifikasi produk baik.

Tahapan selanjutnyan yaitu evaluasi, Adapun kekurangan dari peneliti dalam melakukan pengembangan busana fantasi dengan sumber ide Kekaisaran Jepang menurut ahli produk yaitu, kurangnya peneliti dalam teknik jahitan, karena busana fantasi yang telah peneliti buat kurang rapi dibagian jahitan, sedangkan warna yang peneliti menggunakan banyak mengambil warna, karena peneliti melihat kimono identik dengan keceriaan dengan nuansa colourful serta keanggunan seorang gadis di Jepang.

\section{Hasil Akhir Pengembangan Busana Fantasi Dengan Sumber Ide Kekaisaran Jepang.}

Dari hasil penelitian yang telah penelitian pengembangan busana fantasi dengan sumber ide kekaisaran Jepang terdapat sebuah proses pengembangan busana fantasi yang terdiri dari 2 jenis busana fantasi dimana setiap busana fantasi memiliki karakteristik busana yang berbeda. Terdapat perbedaan diantara busana 1 dan busana 2 dilihat dari model busana pertama menggunakan lengan panjang lengkap dengan bagian kanan dan kiri, sedangkan pada bagian bawah busana terdapat belahan pada bagian depan. Sedangkan busana kedua mengggunakan satu lengan dan dihiasi dengan pembawaan kipas, sedangkan bagian bawah terdapat belahan. Pada busana ini terlihat dari warna dan bentuk yang mencirikan negara Jepang yang terdiri dari warna alam yang memiliki lambang ataupun kepercayaan secara turun-temurun.

Maka hasil dari penelitian diatas, yang peneliti lakukan sama dengan penelitian Busana Pesta Malam Untuk Remaja Dengan Sumber Ide Kain Songket Makasar" yang dilakukan oleh Eni Andriyanti pada tahun 2008 (Jurnal Tata Busana Vol. 3 No.1) Hasil penelitian ini bertujuan untuk (1) Dapat mencipta desain busana malam untuk remaja dengan sumber ide Kain Songket Makassar (2) Membuat busana untuk kesempatan pesta malam untuk remaja dengan sumber ide Kain Songket Makassar (3) Menyelenggarakan pagelaran busana dengan tema "Secret Of Traditional" menampilkan busana pesta malam untuk remaja dengan sumber ide Kain Songket Makassar. Dalam mencipta disain busana pesta malam untuk remaja penyusun mengambil sumber ide Kain Songket Makassar ciri khas motif geometris yang diterapkan pada mode gaun backless sehingga tercipta disain berupa gaun. Dalam pembuatan busana pesta malam untuk remaja dengan sumber ide Kain Songket Makassar ada tiga tahapan yaitu persiapan, pelaksanaan, evaluasi. 
Persiapan yang dilakukan yaitu mendesain busana pesta malam untuk remaja dengan sumber ide Kain Songket Makassar, mengambil ukuran, membuat rancangan bahan skala kecil dan rancangan harga, membeli kain, menyusutkan bahan, membuat pola sebenarnya, memotong bahan, memberi tanda jahitan, menjelujur, passen I, menjahit kemudian passen II.

Terdapat beberapa perbedaan dari hasil penelitian peneliti, diantaranya dimana peneliti menggunakan model penelitian pengembangan ADDIE (analysis, design, development, implementation, evaluation) dan mengikuti prosedur pengembangan sesuai dengan tahapannya, sementara penelitian milik Eni Andriyanti menggunakan metode berbeda dengan peneliti yaitu hanya terdiri dari ada tiga tahapan yaitu persiapan, pelaksanaan, evaluasi., selain itu perbedaan yang lainnya perbedaan sumber ide yang digunakan dalam pembuatan busana, peneliti menggunakan sumber ide yang mengambil dari Kekaisaran Jepang sedangkan Eni Andriyanti menggunakan Kain Songket Makasar sebagai sumber idenya.

Sedangkan persamaan yang peneliti temukan dalam penelitian Eni Andriyanti dengan penelitian peneliti yaitu sama-sama menggunakan sumber ide dalam menciptakan suatu produk, persamaan yang lainnya ditemukan langkah-langkah yang digunakan dalam membuat busana hampir sama dengan peneliti lakukan.

Bedasarkan analisis data deskriptif kualitatif, peneliti dapat simpulkan bahwa isi instrument yang tidak valid, dikarenakan pemilihan bahasa oleh peneliti kurang dimengerti ataupun kurang baku, selain itu butir penilaian yang tidak sesuai dengan apa yang dinilai dalam produk. Sedangkan produk busana fantasi sumber ide Kekaisaran Jepang terdapat kekurangan menurut ahli produk, teknik jahit peneliti yang masih kurang, kurang ditingkatkannya produk karena berupa pengembangan, sedangkan kekurangan yang lain yaitu kurangnya dalam pemilihan warna, dimana peneliti memilih banyak mengambil warna, selain itu Negara Jepang banyak mempercayai warna-warna tertentu yang berasal dari alam sebagai pembawa kebahagian, keberuntungan maupun kasih sayang, sesuai dengan kajian teori yang telah peneliti paparkan sebelumnya.

\section{KESIMPULAN \\ Proses Pengembangan Busana Fantasi Dengan Sumber Ide Kekaisaran Jepang.}

Penelitian pengembangan busana fantasi dengan sumber ide kekaisaran Jepang dapat disimpulkan bahwa pengembangan busana fantasi dengan sumber ide kekaisaran Jepang ini dilakukan dengan berbagai proses dengan mengggunakan langkah pada model penelitian ADDIE (analysis, design, development, implementation, evaluation) dimulai dari menganalisis busana yang akan dibuat, mendesain atau merancang busana, melakukan tahap pengembangan dengan membuat busana fantasi selanjutnya implementasi dengan menguji produk kepada ahli produk busana hingga melakukan evaluasi yang didapat dari review para ahli busana fantasi.

\section{Hasil Pengembangan Busana Fantasi Dengan Sumber Ide Kekaisaran Jepang.}

Adapun metode pengumpulan data yang digunakan dalam pengembangan busana fantasi yaitu angket/kuesioner menggunakan dua orang ahli adapun hasil uji kedua ahli isi dengan nilai 0,91 maka instrumen penilaian pengembangan busana fantasi dengan sumber ide kekaisaran Jepang dapat dikatakan valid.Selanjutnya diuji ahli produk1 dengan nilai $74,54 \%$ dan uji produk ahli 2 dengan nilai $80 \%$ maka dapat dirata-ratakan dengan nilai $77,27 \%$ dengan hasil kualifikasi baik.

Hasil akhir busana fantasi dengan sumber ide kekaisaran Jepang ini terdapat persamaan antara busana satu dengan kedua dari bentuk dan warna, tetapi model busana tersebut berbeda antara busana pertama, terdapat pada lengan dan bawahan dengan busana yang kedua. Busana fantasi dengan sumber ide kekaisaran jepang ini mendapatkan saran dan masukan dari para ahli sebagai acuan kedepannya. 
Jurnal Bosaparis: Pendidikan Kesejahteraan Keluarga

Volume 9, Nomor 3, November 2018

\section{SARAN}

Berdasarkan hasil yang diperoleh pengembangan busana fantasi dengan sumber ide kekaisaran jepang mendapat penilaian baik dari para ahli. Sehingga bisa menjadikan salah satu acuan dalam mengembangkan suatu produk untuk penelitian selanjutnya.

\section{DAFTAR RUJUKAN}

Andriyanti Eni. 2008 Busana Pesta Malam Untuk Remaja Dengan Sumber Ide Kain Songket Makasar. Tugas akhir. Program Studi Teknik Busana Jurusan Pendidikan Boga dan Busana dan Busana Fakultas Teknik Universitas Yogyakarta.

Gakukan Shoi, 2000. Nihon Kokugo Daijiten 6.

Riyanto A. Arifah. 2003. Desain Busana. Bandung : Yapemdo.

Sugiyono. 2012. Metode Penelitian Kuantitatif Kualitatif dan R\&D. Bandung: Alfbeta

http://id.wikipedia.org/wiki/kimono, 2018 